Acta Theriologica $36(3-4): 349$ - 356, 1991.

PL ISSN $0001-7051$

BISONIANA 106

\title{
Ultimobranchial follicles and cysts in the European bison thyroid
}

\author{
Bogusław SAWICKI
}

Sawicki B. 1991. Ultimobranchial follicles and cysts in the European bison thyroid. Acta theriol. 36: $349-356$.

Medial fragments of the left thyroid lobe were examined in 84 European bison, Bison bonasus (Linnaeus, 1758). In 60 of the examined thyroids unusual follicles recognized as the follicles of ultimobranchial origin were noticed. In 9 cases they formed so-colled "preserved" ultimobranchial bodies clearly isolated from the thyroid structure. $\mathrm{C}$ cells were found in the follicles of the ultimobranchial bodies mainly in a typical parafollicular position, like that in the proper thyroid gland.

Department of Histology and Embriology, Medical Academy, Kilińskiego 1, 15-230 Białystok, Poland

Key words: ultimobranchial structures, thyroid, Bison bonasus

\section{Introduction}

The discovery that the thyroid of mammals additionally secrets calcitonin (Hirsch et al. 1963) has aroused great interest in complex composition of the epithelial tissue of this gland. Many questions concerning the preserved fragments of ultimobranchial bodies (Ub), usually treated as remnants of the development, have not been answered yet.

The occurrence of cysts or "unusual" follicles of the Ub bodies was reported in the thyroid of certain mammals: hedgehog, squirrel, guinea pig, rabbit (Watzka 1933); sheep (Van Dyke 1959); golden hamster (Schwartz and Hertzel 1964); raccoon Procyon lotor, kangaroo rat Dipodomys marriami, cotton rat Sigmodon h. hispidus, ground squirrel Spermophilus tridecemlineatus, bushy-tailed wood rat Neotoma cinerea occidentalis, the eastern cotton tail rabbit Sylvilagus floridanus, guinea pig and cat (Sehe 1966); dog, rabbit, cat and laboratory mice (Kameda 1971, Kameda et al. 1980); Indian grey mongoose Herpestes edwarsi (Swarup and Das 1976); house shrew Suncus murinus (Swarup et al. 1978) and man (Harach 1987).

The same structures have also been found in the European bison. These investigations strictly follow the criteria given by Van Dyke (1959) and Bykov (1979) for the Ub bodies.

\section{Material and methods}

The examined European bison Bison bonasus (Linnaeus, 1758), all free-ranging, were selectively shot in the years $1982-1984$ in the Białowieża and Borecka Forests. The thyroid was examined in 84 European bison 
(43 males and 41 females) at the age of 1 month -25 years (Table 1). Three sample were collected from the medial part of the left thyroid lobe of each animal and fixed in Bouin's fluid; $7 \mu$ paraffin sections were stained with $\mathrm{H}+\mathrm{E}$ by the Azan and Grimelius methods modified by Sawicki and Bajko (1974) in order to find out the $\mathrm{C}$ cells.

Table 1. Summary of the material used for the study.

\begin{tabular}{lccc}
\hline Age group & $\begin{array}{c}\text { Calves } \\
<1 \text { year old }\end{array}$ & $\begin{array}{c}\text { Juveniles } \\
1-4 \text { years } \\
\text { old }\end{array}$ & $\begin{array}{c}\text { Adults } \\
>4 \text { years old }\end{array}$ \\
\hline Males & 17 & 10 & 16 \\
Females & 18 & 9 & 14 \\
\hline
\end{tabular}

\section{Results}

In the medial fragments of the thyroid observed in 84 European bison more or less atypical follicles (Fig. 1), and even cysts (Fig. 2), have been found. Size of the follicles, and the cysts in particular, seems to increase along with the animal age (Fig. 2 and 3). Atypical follicles are characterized by shape polymorphism: sometimes it may be a slit-like ramified form (Fig. 2), more often different types of epithelium indents can be seen (Fig. 1 and 4). The epithelial lining of these follicles exhibits heteromorphism, with sudden local changes of the epithelium height from the low monolayer to the high cylindric or multirowed epithelium (Fig. 4 and 5) with cilium in exceptional cases. When indentations are covered with multistratified epithelium, the basal layers of it as a rule reveal C cells of typical parafollicular position (Fig. 4). Most of these follicles are filled with lighter coloid than that found in typical thyroid follicles. Sometimes the coloid is foamy or some atypical follicular contents appear instead.

Among the European bison examined, 60 present features of atypical follicles distinct enough to be classified according to Bykov's criteria (1979) as ultimobranchial follicles. Then, in 32 cases of those 60 the follicles do not form a compact system with typical thyroid follicles, but are situated in the regions of increased number of the connective tissue clearly separating epithelial outgrowths; only in 9 bison they form visibly independent Ub bodies, separated from the typically built thyroid by the connective tissue - in these 9 cases we observed no mutual penetration of structures in both organs (Fig. 6). The Ub bodies isolated in this way consist of losely arranged groups and fascicles of epithelial cells in the connective tissue, among which the follicles of atypical epithelial lining and contents can be found (Fig. 3 and 7). These follicles, most frequently filled with very light, often foamy or microgranular contents, seldom contain typically looking coloid. Relatively often desquamated epithelial cells or so-called "cellular debris" are present in the lumen of bigger follicles or cysts (Fig. 8).

$\mathrm{C}$ cells in the described $\mathrm{Ub}$ bodies demonstrate the same typical parafollicular position, as in the thyroid; however, they can be also encountered in compact cellular groups, fairly often seen in the loose connective tissue, particularly often in calves (Fig. 7). 


\section{Discussion}

The mammalian thyroid, in addition to the follicular cells of long known activity, also displays the presence of $\mathrm{C}$ cells. They can be found having atypical location (Sawicki and Kuczyński 1977); most often, however, they take up a parafollicular position mainly. Foster's assumption (1964) that parafollicular cells of the mammalian thyroid produce calcitonin has been confirmed by numerous investigations. These cells, diferently designated in the past, have finally been given by Pearse (1966) a generally accepted term "C cells".

The fact that the mammalian thyroid contains some other types of epithelial cells seems to be often overlooked.

For a long time groups of interfollicular cells have been additionally recognized among the thyroidal follicles. Aleshin (1973) claims that they initiate the proliferation of the thyroid parenchyma. However, methods of reliable identification of these cells have not been reported yet, leaving their significance still not completely elucidated. The more so because tangential sections of the thyroid follicles also resemble the interfollicular cell groups and therefore their real number is overestimated (Bykov 1979).

The remnants of the $\mathrm{Ub}$ bodies in the mammalian thyroid comprise another completely different group of epithelial cells. Kirkeby (1977) has reported the occurrence of cells of different enzymatic activity in the lining of normal follicles, apart from the typical follicular cells, the author assumes that they are derived directly from the follicular cells of the $\mathrm{Ub}$ bodies.

The Ub bodies originate in lower vertebrates from the endoderm of the furthest branchial clefts (Van Dyke 1959) and remain as an independent endocrine gland throughout life. Calcitoninforming (C) cells, that they contain, demonstrate similar parafollicular position in relation to the follicles of the $\mathrm{Ub}$ bodies to that in the mammalian thyroid (Stoeckle and Porte 1969). Role of follicular cells of the Ub bodies is completely unknown. Besova and Savelier (1989) suggest the existence of mutual interdependence between the two cellular thypes of the Ub bodies, based on mechanisms controlling adjacent cells via paracrine.

Pearse's view (1966) that $C$ cells derive primarily from neuroectoderm of neural crests and then penetrate into the Ub bodies is gaining more and more followers. In mammalian embryos $\mathrm{C}$ cells secondarily move together with the Ub bodies to the thyroid, where these bodies get incorporated. Thus, in the development of mammals the $\mathrm{Ub}$ bodies in carrying $\mathrm{C}$ cells to the thyroid. Finally, a close contact of $\mathrm{C}$ cells with the follicular cells of the thyroid is brought about within the basement membrane (Pearse and Carvalheira 1967). Yet, transformations of follicular cells of the Ub bodies in the process of their assimilation by the thyroid are still obscure. Sehe (1966) assumes that they become degenerated or completely declined. Other authors state that at least some of them get transformed into typical thyreocytes (Calvert 1972, Kameda et al. 1980, Moreno et al. 1969).

It was in 1933 that Watzka noticed distinct influence of direct contact of the mammalian $\mathrm{Ub}$ bodies with the thyroid tissue upon their development. According to him Ub bodies maintain their typical structure only when situated outside the thyroid tissue and their structures, which normally penetrate the inside of the thyroid tissue, become transformed into the thyroid tissue proper. Van Dyke (1959) confirmed the inductive influence of the thyroid 
upon described transformations of the Ub bodies and stressed the tendency towards frequent processes of metaplasia in the preserved Ub structures, which is of essential significance in the genesis of neoplastic tumours in the mammalin thyroid. My investigations of the European bison thyroid confirm the Watzka's observations that a typical, best preserved structure of the Ub bodies can be seen only when clearly separated from the thyroid by the conective tissue (Fig. 6). Also "atypical follicles" within the thyroid are well isolated by the connective tissue from typical structures of this gland in bison. In my opinion adequately early development of significant amount of the connective tissue in the thyroid hilus in bison can protect at least part of the Ub body structure getting through the hilus from the direct contact with thyreocytes. This prevents structural changes of isolated fragments of the gland.

The frequency of the preserved $\mathrm{Ub}$ bodies noted in the present report (9 to 84 of the examined bison) is undoubtedly lowered. Histological examinations using serial sections from the two whole lobes of the thyroid would give much higher number. In our case, such examinations could not be carried out on such a great scale due to insufficient technical means. Nevertheless, the examined medial fragments of the thyroid most often seem to be the only region of the gland to have preserved fragments of the Ub bodies structures in other animals examined (Van Dyke 1959, Bykov 1977 and other authors). My results, though approximate, reveal frequent occurrence of "atypical follicles" in the European bison thyroid. The structure of these follicles evidences their $\mathrm{Ub}$ origin.

In the available literature, comprising the period of the last 30 years, I have not found any data on the occurrence of structures described in the present report, both in European bison and in allied mammals of Bovidae family.

Arnold (1916) described the structure of the thyroid in cattle (fetus, calf and full-animal). He noticed numerous vesicles filled with desquamated cells or granular secretion and so-called cellular debris. He demonstrated the follicles lined with the multistratified epithelium in one of the figures of his work. The above observations made him erroneously assume that the coloid in the cattle thyroid originated from desquamated epithelial cells. Our present knowledge lets us, however, think that the above description referred to "atypical follicles" of ultimobranchial origin. Therefore, we may assume remnants of the Ub bodies to be as frequent in the cow thyroid as described in European bison.

More detailed information concerning the Ub bodies in the thyroid of cattle can be found in the work of Watzka (1933). Referring to Wolfer and Pernant's examinations of 1894 he claims that "Ub bodies in ox may remain cyst-like in the thyroid". This opinion seems to be confirmed by Trautmann and Fiebiger (1954) - "in extrafetal life they can be found in the thyroid tissue or in its vicinity throughout a varied period of time (the longest in cattle)".

There is essentially important a close morphological link between $\mathrm{C}$ cells and the follicular cells of the $\mathrm{Ub}$ bodies, analogical to that found in the thyroid among its $\mathrm{C}$ cells and follicular cells. Similar observations have been made in lower vertebrates (Besova and Savelier 1989). These authors discern a close cooperation between the follicular cells of $\mathrm{Ub}$ bodies and $\mathrm{C}$ cells by the paracrine regulation. Regulatory mechanisms concerning calcic homeostasia are most likely to be involved here. According to Buffa et al. (1989), also some other biologically active substances and various cell systems, apart from calcitonin and parathormon, appear to be engaged in the processes of calcic homeostasia regulation. 
The literature quoted as well as my own studies prove the need for further detailed studies on the complex system of the epithelial cells forming the thyroid gland in order to demonstrate the cellular composition of the organ as well as to elucidate the cooperation mechanisms in particular types of the epithelial cells of the thyroid gland.

\section{References}

Aleshin R. V. 1973. Sources and regulation of the thyroid growth. Arkh. Anat. Gistol. Embriol. 65, 10: 5 - 18. [In Russian with English summary]

Arnold E. 1916. Histologie der Schilddrüse des Rindes in verschidenen Altersstadien. Arch. wiss. prakt. Tierheilk. 42: $369-391$.

Besova N. V. and Savelier S. V. 1989. Anlage and development of the ultimobranchial gland in embryogenesis of amphibia. Arkh. Anat. Gistol. Embriol. 97: 70 - 76. [In Russian with English summary]

Buffa R., Mare P., Salvadore M., Solcia E., Furness J. B. and Lawson D. E. 1989. Calbindin 28 kDa in endocrine cells of known or putative calcium-regulating function. Thyro-parathyroid C cells, gastric ECL, intestinal secretin and enteroglucagon cells, pancreatic glucagon, insulin and PP cells, adrenal medullary NA cells and some pituitary (TSH?) cells. Histochemistry 91: $107-113$.

Bykov V. L. 1977. Ultimobranchial follicles and cysts in the thyroid gland of mice. Arkh. Anat. Gistol. Embriol. 72: 59 - 64. [In Russian with English summary]

Bykov V. L. 1979. Heterogeneity of the thyroid gland in mammals and age changes of the organ. Arkh. Anat. Gistol. Embriol. 77, 10:61 - 71. [In Russian with English summary]

Calvert R. 1972. Transitional cells in the postnatal thyroid gland of the rat. Anat. Rec. 174: $341-359$.

Forster G. V., Mac Intyre I. and Pearse A. G. E. 1964. Calcitonin production and mitochondrionrich cells of dog thyroid. Nature (London) 203: $1029-1030$.

Harach H. R. 1987. Mixed follicles of the human thyroid gland. Acta anat. (Basel) 129: $27-30$.

Hirsch P. F., Gauthier G. F. and Munson P. L. 1963. Thyroid hypocalcemic principle and recurrent laryngeal nerve injury as factors affecting the response to parathyroidectomy in rats. Endocrinology $73: 244-252$.

Kameda Y. 1971. The occurrence and distribution of the parafollicular cells in the thyroid, parathyroid IV and thymus IV in some mammals. Arch. histol. jap. 33: 283 - 299.

Kameda Y., Shigemoto H. and Ikeda A. 1980. Development and cytodifferentiation of C cells complex in dog fetal thyroid. An immunohistochemical study using anti-calcitonin, anti-C-thyroglobulin and anti-19S thyreoglobulin antisera. Cell Tissue Res. 203: 403 - 415 .

Kirkeby S. 1977. Esterase activity in the guinea pig thyroid under normal and pathological conditions (vitamin A deficiency) with special regard to cyst-like structures. Virchows Arch. B Cell Path. 23: 129 - 136.

Moreno A. M., Martin-Lacave I., Montero C., Gomez P. A., Fernandez A. and Galera H. 1989. Demonstration of sugar residues in the ultimobranchial tubule and thyroid C-cells of the rat using peroxidase labelled lections. Anat. Histol. Embryol. 18: $114-121$.

Perase A. G. E. 1966. 5-Hydroxytryptophan uptake by dog thyroid C cells, and its possible significance in polypeptide hormone production. Nature (London) 211: $598-600$.

Pearse A. G. E. and Carvalheira A. F. 1967. Cytochemical evidence for an ultimobranchial origin of rodent thyroid C cells. Nature (London) 214: $929-930$.

Sawicki B. and Bajko K. 1974. Introduction of double impregnation in the method of Grimelius. Folia morphol. 33: $45-51$.

Sawicki B. and Kuczyński M. 1977. Morphological studies on the C cells of the thyroid of certain rodents. Acta theriol. 22: $251-260$.

Sehe C. T. 1966. Observation of the ultimobranchial gland in small wild and laboratory mammals, with special reference to the histochemical localization of polysaccharides. J. Morphol. 120: $425-442$.

Stoeckle M. E. and Porte A. 1970. Origine embryonnaire et différentation sécrétoire de cellules à calcitonine (vellules C) dans la thyroide foetale du rat. Z. Zellforsch. 106: $251-268$. 
Swarup K. and Das V. K. 1976. Calcitonin cells and unusual follicles of the thyroid of the Indian grey mongoose, Herpestes edwardsi (Geoffroy). Acta anat. (Basel) 95: 384 - 398.

Swarup K., Srivastar A. K. and Tewari N. P. 1978. Occurrence of calcitonin cells and cysts in the parathyroid of the house shrew, Suncus murinus. Acta anat. (Basel) 101: $340-345$.

Schwartz G. E. and Hertzel N. E. 1964. The development of the ultimobranchial bodies and their relationship to thyroid formation in the golden hamster. Trans Amer. microscop. Soc. 83: $384-391$.

Trautmann A. and Fiebiger J. 1954. Histologia i mikroskopowa anatomia porównawcza zwierząt domowych. PWRiL. Warszawa: 1 - 133.

Van Dyke J. H. 1959. The ultimobranchial body. [In: Comparative endocrinology, Proceedings symposium on comparative endocrinology, New York 1958. A. Gordman, ed.]. John Wiley. New York: 320 - 339.

Watzka M. 1933. Vergleichende Untersuchungen über den ultimobranchialen Körper. Z. mikrosk. anat. Forsch. $34: 485-533$.

Received 29 April 1991, accepted 22 August 1991.

\section{EXPLANATION OF PLATES I-II}

\section{Plate I}

Fig. 1. Female, age 7 years. The thyroid fragment. Atypical follicles of very irregular shape are seen. They are lined with the epithelium of varying hight, stratified in places. The follicular lumen displays a very light substance or fine-grained stuff with varied number of desquamated cells. H + E. Enl. $\times 310$.

Fig. 2. Female, age 7 years. Fragment of the Ub body. Larger sizes of cysts and more distinct polymorphism of cysts and follicles as compared to young animals are seen (comp. Fig. 3). H + E. Enl. $\times 80$.

Fig. 3. Male, age 2 years. Fragment of the Ub body. Many cysts and follicles of the Ub body reveal fine-grained mass and numerous desquamated cells. Azan. Enl. $\times 80$.

Fig. 4. Male, age 2 months. Ub follicles and fragment of the cyst in the thyroid. The cyst lining indents to the inside mainly due to a local increase of the epithelium hight: monolayer cylindrical epithelium changes into multistratified or multirowed one - the last case presents basal layers of the epithelium containing $\mathrm{C}$ cells (stained black). The cyst lumen is filled with coloid and debris of desquamated cells. The follicles demonstrate more liquid, foamy contents. Grimelius. Enl. $\times 310$.

\section{Plate II}

Fig. 5. Female, age 5 years. Fragment of an extensive cyst filled with "cellular debris". The cyst wall is lined with the multirowed epithelium. Azan. Enl. $\times 790$.

Fig. 6. Female, age 7 years. Borderline fragments of the thyroid (T) seen on the right side and the Ub body (Ub) on the left and in the centre. Follicles of the Ub body are more loosely positioned in the abundant connective tissue as compared with the thyroid; the $\mathrm{Ub}$ body also presents greater polymorphism of its structures. $\mathrm{H}+\mathrm{E}$. Enl. $\times 24$.

Fig. 7. Female, age 8 months. Fragment of the Ub body. The upper follicle is lined with the multirowed epithelium, the lower mostly with the stratified one. C cells (stained black) are positioned parafollicularly in both follicles, also showing up outside the follicles in the interfollicular cell groups of the connective tissue. Grimelius. Enl. $\times 310$.

Fig. 8. Male, age 3 years. Fragment of the Ub body. The so-called "cellular debris" can be observed within the cyst and two follicles above. C cells, stained black, assume a typical parafollicular position. Grimelius. Enl. $\times 310$. 


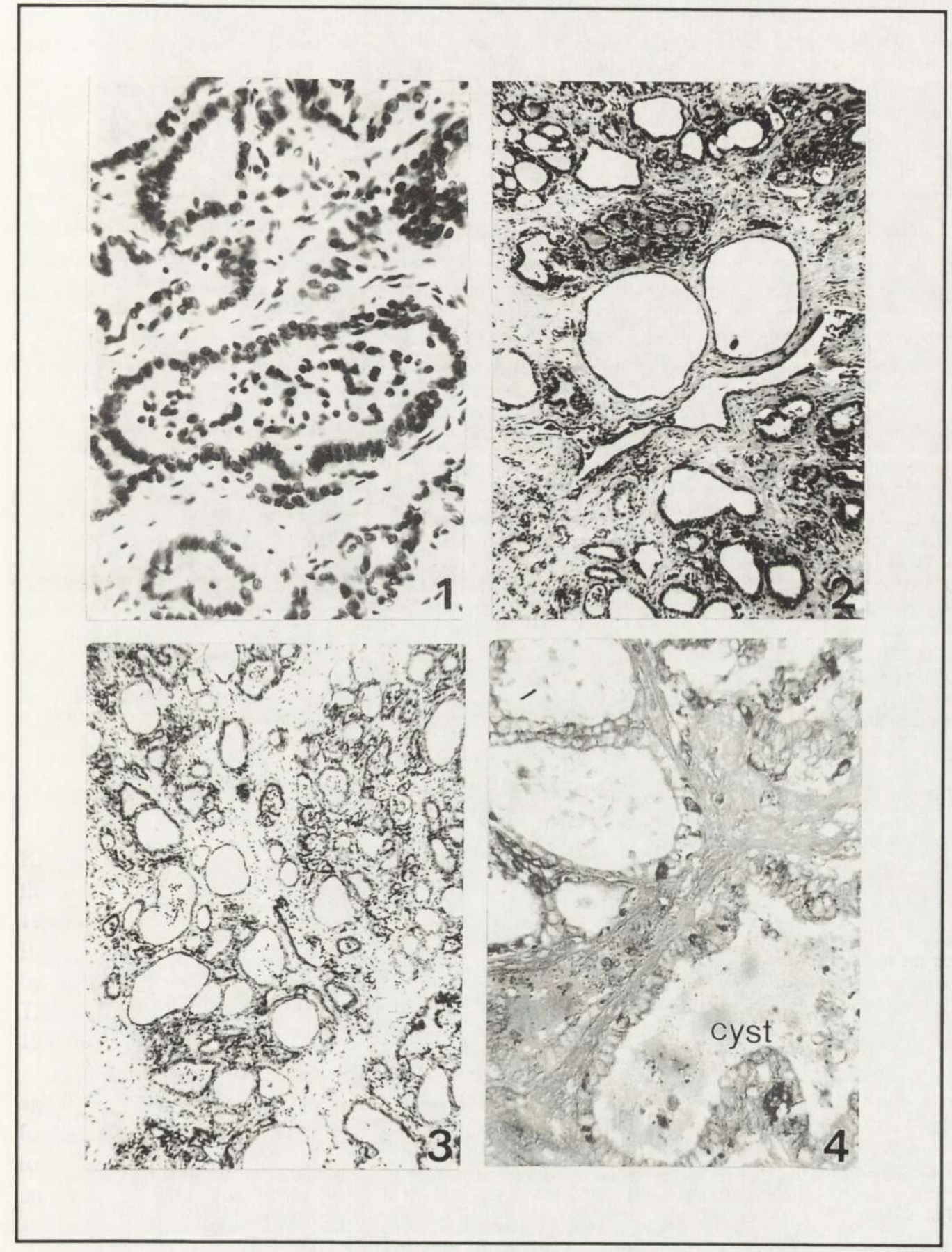


Plate II
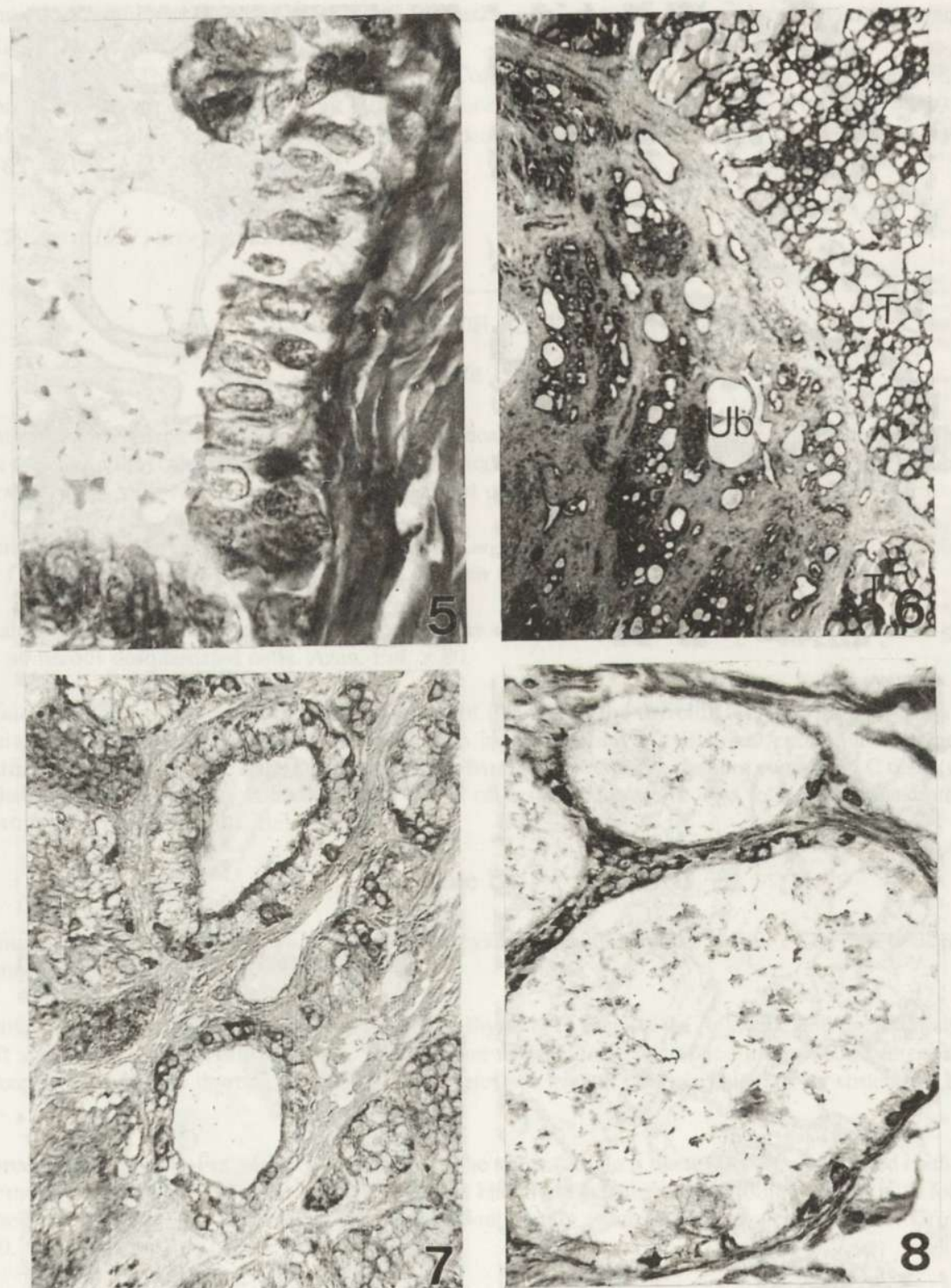